\title{
Papers
}

\section{Isolation measures in the hospital management of methicillin resistant Staphylococcus aureus (MRSA): systematic review of the literature}

\author{
B S Cooper, S P Stone, C C Kibbler, B D Cookson, J A Roberts, G F Medley, G Duckworth, R Lai, S Ebrahim
}

\begin{abstract}
Objective To evaluate the evidence for the effectiveness of isolation measures in reducing the incidence of methicillin resistant Staphylococcus aureus (MRSA) colonisation and infection in hospital inpatients.

Design Systematic review of published articles.

Data sources Medline, Embase, CINAHL, Cochrane Library, System for Information on Grey Literature in Europe (SIGLE), and citation lists (1966-2000).

Review methods Articles reporting MRSA related outcomes and describing an isolation policy were selected. No quality restrictions were imposed on studies using isolation wards or nurse cohorting. Other studies were included if they were prospective or employed planned comparisons of retrospective data.

Results 46 studies were accepted; 18 used isolation wards, nine used nurse cohorting, and 19 used other isolation policies. Most were interrupted time series, with few planned formal prospective studies. All but one reported multiple interventions. Consideration of potential confounders, measures to prevent bias, and appropriate statistical analysis were mostly lacking. No conclusions could be drawn in a third of studies. Most others provided evidence consistent with a reduction of MRSA acquisition. Six long interrupted time series provided the strongest evidence. Four of these provided evidence that intensive control measures including patient isolation were effective in controlling MRSA. In two others, isolation wards failed to prevent endemic MRSA.

Conclusion Major methodological weaknesses and inadequate reporting in published research mean that many plausible alternative explanations for reductions in MRSA acquisition associated with interventions cannot be excluded. No well designed studies exist that allow the role of isolation measures alone to be assessed. None the less, there is evidence that concerted efforts that include isolation can reduce MRSA even in endemic settings. Current isolation measures recommended in national guidelines should continue to be applied until further research establishes otherwise.
\end{abstract}

\section{Introduction}

The incidence of hospital acquired methicillin resistant Staphylococcus aureus (MRSA) continues to rise globally. ${ }^{1-4}$ Attempts to control this spread have relied principally on three measures: hand hygiene among healthcare workers, restriction of antibiotics, and the detection and isolation of infected or colonised patients. We consider the detection and isolation of infected or colonised patients, which is central to most national guidelines. ${ }^{5-8}$

Most transmission of MRSA from patient to patient is thought to be mediated by transiently colonised healthcare workers, although airborne dispersal and transmission through contacts with contaminated surfaces may also be important. Isolation measures for patients are intended to interrupt such transmission. The most intensive forms of isolating patients are isolation wards (designated for the treatment of known or suspected carriers of MRSA) and nurse cohorting (the physical segregation of MRSA patients in one part of a ward, with nursing by designated staff who care exclusively for these patients). Other isolation measures include the use of single bedded rooms, cohorts of patients on general wards (without designated nursing staff), and barrier precautions (use of aprons or gowns, gloves, and, in some cases, masks by healthcare workers as the only physical barrier to transmission).

Such control measures may place substantial burdens on hospital resources, and the value of their continued use has been questioned. ${ }^{9}$ Earlier narrative reviews have been undertaken, ${ }^{10}{ }^{11}$ but the effectiveness of isolation measures in reducing transmission and controlling MRSA has not been assessed systematically. Moreover, as much of the research in this area is known to be of a quasi-experimental nature. ${ }^{811}$ The associated threats to valid inferences need to be considered. ${ }^{12-14}$ We therefore undertook a systematic review of the evidence for the effectiveness of isolation measures in the management of MRSA in hospitals.

\section{Method}

\section{Search strategy}

We developed a search strategy that covers the main subject areas of the review (MRSA, screening, and isolation of patients and control of infection). We searched the following databases, with no language restrictions: Medline 1966-December 2000, Embase 1980-December 2000, CINAHL 1982-May 2000, System for Information on Grey Literature in Europe (SIGLE) 1980-May 2000, and the Cochrane Library to December 2000. We also searched reference lists of retrieved articles and hand searched abstracts from key journals to verify the sensitivity of the search strategy.

\section{Study selection}

Two or three reviewers working together appraised abstracts. Full articles were obtained if abstracts mentioned endemic or epidemic MRSA and an attempt at control in a hospital setting.

As the number of studies was far greater than anticipated, we revised the original protocol (which had imposed no quality 


\begin{tabular}{|c|c|c|c|}
\hline Highest level of isolation & Isolation ward & Nurse cohorting & $\begin{array}{l}\text { Other isolation } \\
\text { measures }\end{array}$ \\
\hline No of studies & 18 & 9 & 19 \\
\hline Range of study durations & 3 months-15 years & 3.5 months- 4 years & 1 month-9 years \\
\hline Whole hospital setting & 16 & 3 & 7 \\
\hline $\begin{array}{l}\text { Hospital unit setting (such as burns, } \\
\text { intensive care) }\end{array}$ & 2 & 6 & 12 \\
\hline \multicolumn{4}{|l|}{ Other control measures } \\
\hline Screening for MRSA & 18 & 9 & 14 \\
\hline Topical eradication therapy & 12 & 5 & 8 \\
\hline Hand hygiene programme & 8 & 2 & 6 \\
\hline Antibiotic restriction & 3 & 0 & 2 \\
\hline \multicolumn{4}{|l|}{ Study design } \\
\hline Prospective interrupted time series & 1 & 2 & 8 \\
\hline Retrospective interrupted time series & 15 & 3 & 2 \\
\hline $\begin{array}{l}\text { Hybrid retrospective and prospective } \\
\text { interrupted time series }\end{array}$ & 0 & 2 & 5 \\
\hline Retrospective cohort study & 0 & 0 & 1 \\
\hline Non-comparative (one phase) studies & 2 & 2 & 3 \\
\hline
\end{tabular}

restrictions). We imposed the minimal requirement that accepted studies should include a component of prospective data collection. If they were entirely retrospective comparisons should have been planned and not prompted by part of the outcome data. No such restrictions were imposed for studies using the most intensive forms of isolation (isolation wards and nurse cohorting) as these have the greatest implications for the allocation of resources and organisation of services.

Two investigators reviewed the papers independently, to confirm that they met the above criteria. We rejected studies not mentioning an isolation policy or without relevant MRSA related outcomes.

\section{Data extraction}

We divided each study into phases, where appropriate, that were defined by major changes in isolation or other aspects of infection control policy and extracted data on study design, patient population, isolation details, screening, other infection control measures, and MRSA related outcomes for patients.
We documented potential threats to the internal validity of accepted studies. We considered the vulnerability of each study to selection, performance, detection, and attrition bias (see table 2). We documented measures taken to prevent bias and noted potential confounders and attempts to record and adjust for these. We documented threats to validity because of underlying trends, seasonal effects, and regression to the mean effects, which we defined as "a tendency for extreme measurements to be followed by less extreme measurements for imperfectly correlated variables that often results in wrong conclusions about the effects of interventions. ${ }^{15}$ We assessed the appropriateness of any statistical analysis undertaken.

We wrote to authors when isolation or screening policies or their timing were unclear. We excluded studies if either the main isolation policy or the timing of interventions were unclear, or if the only outcome reported was MRSA colonisation but the screening policy was unclear or had changed sufficiently to make interpreting outcomes impossible.

\begin{tabular}{|c|c|c|c|}
\hline Type of bias & Cause & Studies vulnerable & Measures taken to identify or prevent bias \\
\hline \multirow[t]{2}{*}{ Selection bias } & \multirow[t]{2}{*}{ Differences in intervention groups on study entry } & \multirow[t]{2}{*}{ Studies without randomisation (39 studies) } & $\begin{array}{l}\text { Four of } 35 \text { interrupted time series studies where isolation } \\
\text { or screening changed presented data allowing comparisons } \\
\text { of patient characteristics between phases }{ }^{26} 344057\end{array}$ \\
\hline & & & $\begin{array}{l}\text { Two described unquantified changes in case mix. }{ }^{43}{ }^{46} \text { One } \\
\text { study presented partial adjustment for confounders }{ }^{30}\end{array}$ \\
\hline \multirow[t]{4}{*}{ Performance bias } & $\begin{array}{l}\text { Differences in care for patients between treatment } \\
\text { groups, apart from interventions under investigation }\end{array}$ & $\begin{array}{l}\text { Studies where specified aspect of care was not under } \\
\text { investigation: }\end{array}$ & \\
\hline & Differences in antibiotic prescribing & 31 interrupted time series studies & $\begin{array}{l}\text { Four presented details of antibiotic use. }{ }^{18223663} \text { Two } \\
\text { alluded to unquantified changes }{ }^{4654}\end{array}$ \\
\hline & Differences in lengths of stay & 29 interrupted time series studies & Changes in length of stay could be assessed in four $r^{33} 364761$ \\
\hline & Differences in bed occupancy and staff workload & 31 interrupted time series studies & $\begin{array}{l}\text { Comparisons of bed occupancy between phases possible in } \\
\text { four }{ }^{18} 244758 \text { Changes in staffing levels or workloads could } \\
\text { be assessed in five }{ }^{1824263247}\end{array}$ \\
\hline \multirow[t]{3}{*}{ Detection bias } & $\begin{array}{l}\text { Differential outcome assessment between intervention } \\
\text { groups: }\end{array}$ & All studies: & Three reported some blinding of outcome assessors ${ }^{34} 4757$ \\
\hline & Differences in diagnosis of infections & 26 studies & $\begin{array}{l}16 \text { specified diagnostic criteria. } 14 \text { reported MRSA } \\
\text { bacteraemias }\end{array}$ \\
\hline & Differences in screening practices & 10 studies with colonisation data only & $\begin{array}{l}\text { In all cases screening effort either reported not to have } \\
\text { changed or to have changed in opposite direction from } \\
\text { outcomes, suggesting screening effort could not explain the } \\
\text { changes }\end{array}$ \\
\hline \multirow[t]{2}{*}{ Attrition bias } & $\begin{array}{l}\text { Differential loss to follow up between treatment } \\
\text { groups. }\end{array}$ & \multirow[t]{2}{*}{$\begin{array}{l}\text { Studies where outcomes are infections ( } 26 \text { studies) } \\
\text { and with substantial changes in length of stay }\end{array}$} & \multirow[t]{2}{*}{$\begin{array}{l}\text { None: no studies followed up patients after discharge to } \\
\text { detect hospital acquired infections }\end{array}$} \\
\hline & $\begin{array}{l}\text { Since hospital acquired infections may first become } \\
\text { apparent after discharge, changes to length of stay } \\
\text { could lead to attrition bias }\end{array}$ & & \\
\hline
\end{tabular}




\begin{tabular}{|c|c|c|c|c|c|}
\hline Study & $\begin{array}{l}\text { Setting and study } \\
\text { population }\end{array}$ & Design & Main interventions & Patient outcomes & Assessment of evidence \\
\hline Coello et al, $1994^{25}$ & $\begin{array}{l}\text { Teaching hospital } \\
1500 \text { beds }\end{array}$ & $\begin{array}{l}\text { Prospective interrupted } \\
\text { time series. Three phases: } \\
8,8 \text {, and } 26 \text { months }\end{array}$ & $\begin{array}{l}\text { Phases } 1 \text { and 2: minimal isolation and } \\
\text { screening } \\
\text { Phase 3: single room isolation and } \\
\text { nurse cohorting, contact screening, } \\
\text { prompt discharge of MRSA cases } \\
\text { Topical eradication of MRSA carriage } \\
\text { with neomcyin nasal cream in phase } 1 \\
\text { and with mupirocin in phases } 2 \text { and } 3\end{array}$ & $\begin{array}{l}\text { Figure: A } \\
476 \text { infected patients } \\
\text { throughout }\end{array}$ & $\begin{array}{l}\text { Evidence that a major outbreak was } \\
\text { controlled by combined interventions. } \\
\text { Lacks information on many potential } \\
\text { confounders }\end{array}$ \\
\hline $\begin{array}{l}\text { Cosseron-Zerbib et al, } \\
1998^{26}\end{array}$ & $\begin{array}{l}\text { Paediatric ICU } \\
20 \text { beds }\end{array}$ & $\begin{array}{l}\text { Hybrid retrospective and } \\
\text { prospective interrupted } \\
\text { time series. Two phases: } \\
21 \text { and } 24 \text { months. }\end{array}$ & $\begin{array}{l}\text { Phase 1: screening for last } 11 \text { months } \\
\text { Phase 2: single room isolation, } \\
\text { cohorting, screening, feedback, } \\
\text { handwashing education, barrier } \\
\text { nursing, chlorhexidine soap, and other } \\
\text { measures }\end{array}$ & $\begin{array}{l}\text { Figure: B } \\
\text { MRSA infections: } \\
\text { Phase 1: } 50 \\
\text { Phase 2: } 6\end{array}$ & $\begin{array}{l}\text { Evidence that interventions reduced } \\
\text { MRSA infections. Regression to mean } \\
\text { and Hawthorne effects supply less } \\
\text { plausible alternative explanations }\end{array}$ \\
\hline Duckworth et al $1988,{ }^{28}$ & $\begin{array}{l}\text { Teaching hospital } \\
645 \text { beds }\end{array}$ & $\begin{array}{l}\text { Retrospective interrupted } \\
\text { time series. Six phases: } 4 \text {, } \\
3,13.5,4,1.5,26 \text { months }\end{array}$ & $\begin{array}{l}\text { Initial isolation: mainly single rooms } \\
\text { and some cohorting (phases } 1-3 \text { ), } \\
\text { changing to mainly isolation ward } \\
\text { (phases 4-6). Simultaneous changes to } \\
\text { screening, eradication and other } \\
\text { measures }\end{array}$ & $\begin{array}{l}\text { Figure: } \mathrm{C} \\
\text { 408 MRSA infections } \\
\text { throughout }\end{array}$ & $\begin{array}{l}\text { Evidence supporting efficacy of } \\
\text { combined measures in reducing } \\
\text { incidence. Many potential confounders } \\
\text { not recorded }\end{array}$ \\
\hline Faoagali et al, $1992^{31}$ & $\begin{array}{l}\text { Teaching hospital } \\
1200 \text { beds }\end{array}$ & $\begin{array}{l}\text { Retrospective interrupted } \\
\text { time series. Two phases: } 7 \\
\text { and } 8 \text { years }\end{array}$ & $\begin{array}{l}\text { Isolation ward throughout } \\
\text { Phase 1: minimal overflow from } \\
\text { isolation ward } \\
\text { Phase 2: overflow isolated in single } \\
\text { rooms } \\
\text { Additional measures in phase } 2 \\
\text { include: pre-screening of admissions } \\
\text { and transfers in; handwashing } \\
\text { education; antibiotic restriction }\end{array}$ & Figure: D & $\begin{array}{l}\text { Evidence that combined measures in } \\
\text { both phases failed to prevent MRSA } \\
\text { spreading and becoming endemic }\end{array}$ \\
\hline Farrington et al, $1998^{32}$ & $\begin{array}{l}\text { Teaching hospital } \\
1000 \text { beds }\end{array}$ & $\begin{array}{l}\text { Retrospective interrupted } \\
\text { time series. Two phases: } \\
9.5 \text { and } 2.5 \text { years }\end{array}$ & $\begin{array}{l}\text { Continual operation of isolation ward } \\
\text { Phase 1: minimal overflow from } \\
\text { isolation ward } \\
\text { Phase 2: overflow cohorted and } \\
\text { isolated in single rooms } \\
\text { Screening, ward closure and } \\
\text { eradication policies relaxed slightly in } \\
\text { phase 2 }\end{array}$ & $\begin{array}{l}\text { Figure: } \mathrm{E} \\
221 \text { MRSA acquisitions, } \\
206 \text { colonised on } \\
\text { admission, } 61 \text { uncertain }\end{array}$ & $\begin{array}{l}\text { Evidence supporting control of MRSA } \\
\text { for } 9.5 \text { years by combined measures } \\
\text { followed by eventual control failure } \\
\text { related to rise in numbers colonised on } \\
\text { admission or to change in strain rather } \\
\text { than changed control measures }\end{array}$ \\
\hline $\begin{array}{l}\text { Harbath et al, } 2000,{ }^{35} \text { Pittet } \\
\text { et al, } 2000^{36}\end{array}$ & $\begin{array}{l}\text { Teaching hospital } \\
1300-1600 \text { beds }\end{array}$ & $\begin{array}{l}\text { Hybrid retrospective and } \\
\text { prospective interrupted } \\
\text { time series. Three phases: } \\
4,2 \text {, and } 3 \text { years }\end{array}$ & $\begin{array}{l}\text { Phase 1:No control measures } \\
\text { Phase 2: Single room isolation, } \\
\text { screening, mupirocin } \\
\text { Phase } 3 \text { : as phase } 2+\text { hand hygiene, } \\
\text { education, and feedback programme }\end{array}$ & $\begin{array}{l}\text { Figure: F } \\
1771 \text { MRSA colonisations } \\
\text { and infections. } 158 \\
\text { bacteraemias }\end{array}$ & $\begin{array}{l}\text { Evidence supporting control by } \\
\text { combined interventions } \\
\text { Some potential confounders, but these } \\
\text { provide less plausible explanations for } \\
\text { the changes }\end{array}$ \\
\hline
\end{tabular}

Disagreements between reviewers were resolved by discussion and recourse to third parties. Reviewers were not permitted to play any part in appraising a study in which they had participated.

\section{Data synthesis}

Two reviewers independently evaluated the strength of evidence in each study by examining the study design, quality of data, and presence of plausible alternative explanations of outcomes. They characterised the evidence on a case by case basis as "none," "weak," "of intermediate strength," or "stronger." We considered formal meta-analysis inappropriate because of heterogeneity in outcome measures and patient populations. Full details of the search strategy, study selection, and data extraction are available in a technical report. ${ }^{16}$

\section{Results}

The electronic search selected 4382 abstracts. Hand searching produced no additional papers. Appraisal of abstracts selected 254 papers, including 20 in languages other than English. The final review included 46 studies (table 1). ${ }^{17-63}$

\section{Study design}

We found no randomised controlled trials and only four prospective planned comparison studies with predefined study phases. ${ }^{22} 40{ }^{52}{ }^{33}$ Most designs were interrupted time series-that is, time series of outcome measures recorded before and after one or more interventions. However, eight of 38 interrupted time series studies presented only collapsed data, summarising time series from each phase in a single data point. One retrospective cohort study used survey data from all Dutch hospitals. ${ }^{30}$

Ten studies did not compare isolation or screening measures with respect to isolation or screening. ${ }^{17} 333741444956596062$ Review of the 36 studies allowing comparisons between isolation policies indicated that in 27 the comparisons being made were dependent on knowledge of the outcome data. Short retrospective studies with successful outcomes were particularly vulnerable to this problem; in at least seven the decision to intervene was influenced by part of the outcome data reported. This, and the predominance of unplanned retrospective reports, shows that reporting bias is likely to be important.

\section{Threats to internal validity of evidence}

In the absence of cluster randomised trials, all comparative studies were vulnerable to selection bias, yet recording and adjustment of potential confounders was minimal (table 2). In two cases we considered reported changes in case mix to represent a plausible explanation for changes in the incidence of MRSA. $^{43} 46$

We identified changes in antibiotic prescribing, staff workload and ratios of staff to patients, and lengths of stay as the main potential sources of performance bias. Again, few studies reported data allowing an assessment of these, and none provided adjustment in the analysis (table 2). In a few cases some 


\begin{tabular}{|c|c|c|c|c|c|}
\hline Study & $\begin{array}{l}\text { Setting and study } \\
\text { population }\end{array}$ & Design & Main interventions & Outcomes & Assessment of evidence \\
\hline $\begin{array}{c}\text { Arnow et al, } \\
1982^{18}\end{array}$ & Burns unit, 8 beds & $\begin{array}{l}\text { Hybrid retrospective and } \\
\text { prospective interrupted } \\
\text { time series. Two phases of } \\
8.5 \text { months each }\end{array}$ & $\begin{array}{l}\text { Phase 1: barrier precautions only } \\
\text { Phase } 2 \text { nurse cohorting, handwashing } \\
\text { education, increased screening }\end{array}$ & $\begin{array}{l}\text { MRSA cases: } 39 \text { (phase 1); } \\
6 \text { (phase 2). } \\
\text { No new cases occurred during } \\
\text { periods when nurse cohorting was } \\
\text { complete }\end{array}$ & $\begin{array}{l}\text { Evidence supporting control by } \\
\text { interventions. Variation in patient-bed } \\
\text { days is a plausible alternative } \\
\text { explanation. Regression to the mean } \\
\text { effects are possible }\end{array}$ \\
\hline $\begin{array}{l}\text { Blumberg et al, } \\
1995^{22}\end{array}$ & $\begin{array}{l}\text { Intensive care unit } \\
\text { ( } 20 \text { beds), paediatric } \\
\text { oncology ( } 15 \text { beds), } \\
\text { and non-targeted areas } \\
\text { of a tertiary care } \\
\text { hospital ( } \sim 3000 \text { beds) }\end{array}$ & $\begin{array}{l}\text { Hybrid interrupted time } \\
\text { series. One year cohort } \\
\text { study with non-equivalent } \\
\text { concurrent controls, one } \\
\text { year historical controls, and } \\
\text { one year follow up }\end{array}$ & $\begin{array}{l}\text { No control measures before study } \\
\text { (historical controls). During } \\
\text { intervention year eradication, screening } \\
\text { and patient isolation (single rooms and } \\
\text { staff cohorting) used in ICU and } \\
\text { paediatric oncology. Measures largely } \\
\text { abandoned in follow up year. }\end{array}$ & $\begin{array}{l}299 \text { MRSA bacteraemias (43 in } \\
\text { areas with interventions) } \\
\text { Bacteraemias fell in the intervention } \\
\text { year in targeted areas, then rose to } \\
\text { intermediate levels in the } \\
\text { post-intervention year. They increased } \\
\text { each year in non-targeted areas }\end{array}$ & $\begin{array}{l}\text { Evidence supporting control by } \\
\text { interventions. Regression to the mean } \\
\text { effects likely, and study vulnerable to } \\
\text { changes in length of stay }\end{array}$ \\
\hline $\begin{array}{r}\text { Cox et al, } \\
1995^{27}\end{array}$ & $\begin{array}{l}\text { One general hospital } \\
\text { (hospital } A \text { ) and two } \\
\text { long stay or rehab } \\
\text { hospitals (B and } C \text { ). } \\
750 \text { beds in total }\end{array}$ & $\begin{array}{l}\text { Retrospective interrupted } \\
\text { time series. Three phases } \\
\text { (at hospital A): } 5,4 \text {, and } 11 \\
\text { months }\end{array}$ & $\begin{array}{l}\text { Phase } 1 \text { : single rooms and cohorting } \\
\text { Phase } 2 \text { and } 3 \text { : isolation wards } \\
\text { Eradication and extensive screening } \\
\text { throughout, including pre-admission } \\
\text { from phase } 2\end{array}$ & $\begin{array}{l}83 \text { MRSA infected patients, } 334 \\
\text { colonisations. } \\
\text { Hospital A: } 1-4 \text { infections/month in } \\
\text { all phases. Last month of data } \\
\text { collection showed very low } \\
\text { colonisation incidence } \\
\text { Hospital B: Continual detection of } \\
\text { MRSA cases. No clear trend } \\
\text { Hospital C: apparent elimination of } \\
\text { MRSA } 14 \text { months after isolation } \\
\text { ward opened }\end{array}$ & $\begin{array}{l}\text { Evidence that combined measures in } \\
\text { all phases failed to prevent sustained } \\
\text { spread at hospital A. No evidence of } \\
\text { control at hospital B. Weak evidence of } \\
\text { control at hospital C. Interpretation of } \\
\text { hospital B and C data difficult without } \\
\text { colonisation on admission data due to } \\
\text { interhospital transfers }\end{array}$ \\
\hline $\begin{array}{l}\text { Esveld et al, } \\
1999^{30}\end{array}$ & $\begin{array}{l}\text { Dutch hospitals with } \\
\text { index MRSA cases } \\
\text { responding to a } \\
\text { questionnaire. } \\
231 \text { returned } \\
\text { questionnaires }\end{array}$ & $\begin{array}{l}\text { Two year retrospective } \\
\text { cohort study based on } \\
\text { systematically collected } \\
\text { survey data }\end{array}$ & $\begin{array}{l}\text { Two cohorts defined by isolation policy } \\
\text { Isolation cohort: index cases isolated } \\
\text { on admission according to Dutch } \\
\text { guidelines } \\
\text { Non-isolation cohort: other isolation } \\
\text { policy or delayed isolation }\end{array}$ & $\begin{array}{l}\text { Isolation cohort: } 4 \text { out of } 73 \text { cases } \\
\text { led to secondary spread } \\
\text { Non-isolation cohort: } 19 \text { out of } 95 \\
\text { cases led to secondary spread. } \\
\text { Odds ratio } 4.3(95 \% \mathrm{Cl} 1.3 \text { to } \\
\text { 18.2) }\end{array}$ & $\begin{array}{l}\text { Evidence that immediate isolation } \\
\text { contributed to control. Other plausible } \\
\text { explanations include: differences in } \\
\text { strains (prompt isolation was } \\
\text { associated with strains originating } \\
\text { abroad); differences in characteristics } \\
\text { of cohorts and settings; and bias } \\
\text { introduced by differential response } \\
\text { rates to questionnaires }\end{array}$ \\
\hline $\begin{array}{l}\text { Jernigan et al, } \\
1996^{38}\end{array}$ & $\begin{array}{l}\text { Neonatal intensive care } \\
\text { unit, } 33 \text { beds }\end{array}$ & $\begin{array}{l}\text { Hybrid retrospective and } \\
\text { prospective interrupted } \\
\text { time series. Two phases: } \\
12 \text { days and } 9 \text { months }\end{array}$ & $\begin{array}{l}\text { Phase 1: contact isolation (gloves, } \\
\text { gowns, masks and use of two bedded } \\
\text { side-room if possible) } \\
\text { Phase 2: as phase 1 plus eradication } \\
\text { from selected patients; weekly } \\
\text { screening; handwashing education }\end{array}$ & $\begin{array}{l}\text { Total cases: } 16 \text { ( } 5 \text { in phase } 1,11 \text { in } \\
\text { phase } 2 \text { ). Large fall in incidence } \\
\text { after additional control measures } \\
\text { Relative risk of transmission from } \\
\text { an unisolated compared to an } \\
\text { isolated source } 15.6 \text { (( } 95 \% \text { Cl } 5.3 \\
\text { to } 45.6), P<0.0001\end{array}$ & $\begin{array}{l}\text { Evidence supporting reduction in } \\
\text { MRSA transmission by isolation } \\
\text { measures } \\
\text { Potential bias as no blinding to the } \\
\text { isolation status of patients when } \\
\text { assessing transmission sources } \\
\text { Regression to the mean effects possible }\end{array}$ \\
\hline $\begin{array}{l}\text { Kac et al, } \\
2000^{40}\end{array}$ & $\begin{array}{l}\text { Wound care centre, } \\
51 \text { beds }\end{array}$ & $\begin{array}{l}\text { Prospective interrupted } \\
\text { time series. Two phases: } 3 \\
\text { months and } 2 \text { years }\end{array}$ & $\begin{array}{l}\text { Phase 1: no measures } \\
\text { Phase 2: gowns and gloves, } \\
\text { handwashing education, feedback of } \\
\text { infection rates, MRSA wounds dressed } \\
\text { last }\end{array}$ & $\begin{array}{l}15 \text { wound infections. Reduction in } \\
\text { proportion of patients acquiring } \\
\text { MRSA wound infections from } 6 / 70 \\
(9 \%) \text { to } 9 / 583(1.5 \%)\end{array}$ & $\begin{array}{l}\text { Evidence that control measure } \\
\text { reduced infection rates, but limited } \\
\text { by short baseline and vulnerable to } \\
\text { pre-existing trends (due to lack of } \\
\text { time series data). Impossible to } \\
\text { distinguish cross-infection and } \\
\text { autoinfection }\end{array}$ \\
\hline $\begin{array}{r}\text { Murray Leisure } \\
\text { et al, } 1990^{46}\end{array}$ & $\begin{array}{l}\text { General hospital, } \\
884 \text { beds }\end{array}$ & $\begin{array}{l}\text { Retrospective interrupted } \\
\text { time series. two phases: } 32 \\
\text { and } 12 \text { months }\end{array}$ & $\begin{array}{l}\text { Phase 1:Single room isolation } \\
\text { Phase 2: Isolation ward and changes to } \\
\text { screening }\end{array}$ & $\begin{array}{l}177 \text { new MRSA cases } \\
\text { MRSA cases increased throughout } \\
\text { phase } 1 \text { then fell to low levels in } \\
\text { phase } 2\end{array}$ & $\begin{array}{l}\text { Evidence consistent with control by } \\
\text { isolation ward and screening, but } \\
\text { change in numbers colonised on } \\
\text { admission provides a plausible } \\
\text { alternative explanation }\end{array}$ \\
\hline $\begin{array}{l}\text { Selkon et al, } \\
1980^{54}\end{array}$ & $\begin{array}{l}\text { Teaching hospital, } \\
1000 \text { beds }\end{array}$ & $\begin{array}{l}\text { Retrospective interrupted } \\
\text { time series. Two phases of } \\
5.5 \text { years each }\end{array}$ & $\begin{array}{l}\text { Phase 1: single room isolation } \\
\text { Phase 2: isolation ward }\end{array}$ & $\begin{array}{l}965 \text { MRSA infections } \\
\text { MRSA infections increased before } \\
\text { the opening of isolation ward, and } \\
\text { subsequently decreased }\end{array}$ & $\begin{array}{l}\text { Evidence consistent with control by } \\
\text { isolation ward } \\
\text { Changing antibiotic use provides a } \\
\text { plausible alternative explanation }\end{array}$ \\
\hline
\end{tabular}

information was available that implied that performance bias could plausibly explain changes in MRSA outcomes. ${ }^{54} 182233$

Similarly, studies took few measures (such as blinding of outcome assessors) to prevent detection bias, although we considered studies reporting infections with specified diagnostic criteria and bacteraemias as primary outcomes to be less vulnerable to this bias.

\section{Trends, regression to the mean, and seasonal effects}

Of 30 studies with two or more phases and pre-intervention time series, clear trends were apparent in 13. In all cases the trend was for increasing MRSA levels before major interventions.

Trends in the number of patients colonised on admission may also complicate interpretation of outcomes. Of 35 studies presenting time series data, only five of the 18 studies that assessed whether patients were colonised on admission presented sufficient data to assess trends. In two cases there was an increasing trend, ${ }^{32}{ }^{50}$ in one a decreasing trend, ${ }^{46}$ and in two no clear trend. ${ }^{3340}$ In two cases these trends provided a plausible explanation for changes in outcome measures. ${ }^{32} 46$

Regression to the mean effects were considered likely when unusually high MRSA incidence data prompted the intervention and when these data were included in the study. We considered this threat to provide a plausible explanation of outcomes in seven studies. $^{1822} 2324474858$

Inspection showed that seasonal effects may have been important in two ${ }^{23} 58$ of 14 studies with time series of 18 months or more. In the 21 studies with shorter time series it was not possible to disentangle seasonal from intervention effects.

Changes in MRSA strain types may explain changes in outcomes. Fourteen studies reported no typing details. In one study we considered the documented introduction of a new strain believed to have greater epidemic potential to plausibly explain increased MRSA incidence and control failure. ${ }^{32}$ 

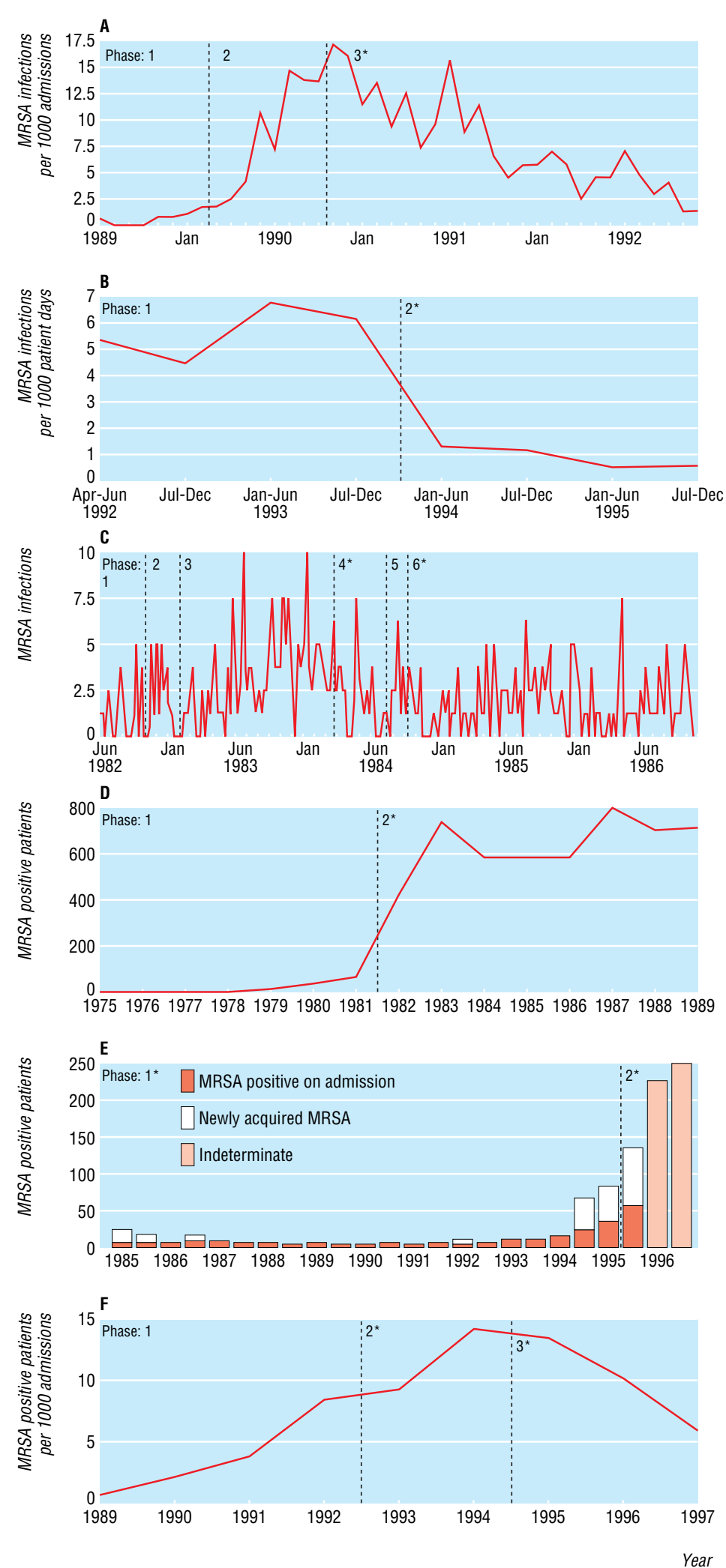

Outcome of studies considered to present the strongest evidence Interrupted time series for A: Coello et a ${ }^{25} \mathrm{~B}$ : Cosseron Zerbib et al ${ }^{26} \mathrm{C}$ : Duckworth et a ${ }^{28} \mathrm{D}$ : Faoagli et $\mathrm{al}^{31} \mathrm{E}$ : Farrington et al ${ }^{32} \mathrm{~F}$ : Harbath et al. ${ }^{35}{ }^{36}$ Table 3 gives explanatory text. Asterisks indicate phases with most intensive isolation policies. In $\mathrm{D}$ and $\mathrm{E}$ isolation policies in both phases were similar (isolation wards), but in the second phase the capacities of the isolation wards were exceeded in both cases, and the overflow was cohorted or isolated in single rooms 


\section{Statistical validity}

Of the 38 interrupted time series, 24 reported results of statistical analysis. In all but one study ${ }^{38}$ where the analysis could be assessed patient outcomes were assumed by authors to be independent. Such assumptions are inappropriate when transmission from patient to patient occurs and would cause inflated rates of type I errors. In one study we considered the independence assumption to be justified as outcomes at hospital level from distinct hospitals were used. ${ }^{30}$

\section{Evidence for control of MRSA}

In 45 of the 46 studies multiple simultaneous control measures were apparent. It was not possible to assess the relative contribution of individual measures.

In 14 studies it was impossible to draw any conclusions about the effect of interventions. Most of the remaining 32 reported evidence consistent with reduction in MRSA transmission. The evidence in 18 of these we considered weak, because of poor study design or clear alternative explanations. This often applied to small and successfully controlled outbreaks managed by isolation wards or nurse cohorting. ${ }^{17} 1939505153555661$ None the less, it remains possible that immediate deployment of nurse cohorting or an isolation ward may be successful. Fourteen studies provided "stronger" evidence or evidence of intermediate strength (tables 3 and 4).

The strongest evidence came from six longer time series, with detailed information on interventions and fewer plausible alternative explanations (table 3, figure). In four cases major outbreaks were controlled or MRSA numbers substantially reduced over prolonged periods ${ }^{25} 26283536$; the main isolation measures were single room in two studies, ${ }^{26}{ }^{35} 36$ nurse cohorting in one, ${ }^{25}$ and isolation ward in one. ${ }^{28}$ Another isolation ward study reported failure to control the spread of MRSA, ${ }^{31}$ and another reported control by an isolation ward for many years followed by eventual failure. ${ }^{32}$

We considered eight studies (table 4) to present evidence of reduction of MRSA by measures that included an isolation ward ${ }^{46}{ }^{54}$ nurse cohorting, ${ }^{16}{ }^{20}$ or other interventions. ${ }^{30} 38{ }^{40}$ One presented data indicating the failure of an isolation ward to control MRSA. ${ }^{27}$ However, these studies either had plausible alternative explanations or reported smaller changes in MRSA and did not record some important potential confounders. The evidence was therefore considered weaker than that from the first six. We found evidence from only one study that supported the hypothesis that MRSA replaces methicillin-sensitive Staphylococcus aureus (MSSA). ${ }^{43}$ MRSA and MSSA bacteraemia data from the longer time series ${ }^{31}{ }^{32}{ }^{36}$ contradicted this and showed that MRSA added to the total burden of infection.

\section{Discussion}

Our primary conclusion is that major methodological weaknesses and inadequate reporting in research into the effectiveness of isolation measures mean that many plausible alternative explanations for reductions in MRSA cannot be excluded. We have produced guidelines to facilitate the planning and publication of better quality studies. ${ }^{16}$

The secondary conclusion is that, despite the limitations of existing research we found evidence that concerted interventions that include isolation measures can reduce MRSA transmission substantially, even in settings with endemic MRSA. We found no evidence to show that current isolation measures recommended in many countries ${ }^{5-8}$ are ineffective at reducing transmission from isolated patients: the only two studies that directly measured this reported large reduction in the transmis-

\section{What is already known on this topic}

National guidelines in many countries recommend patient isolation to control the spread of MRSA

Traditional narrative reviews differ as to its effectiveness

Most of the research is of a quasi-experimental nature, and no review has systematically assessed the threats to valid inference associated with such studies

\section{What this study adds}

The shortcomings of existing research are rigorously evaluated through a systematic comprehensive search strategy, data extraction, and documentation of component threats to validity

Major methodological weaknesses and inadequate reporting in many studies mean that plausible alternative explanations for reductions in MRSA cannot be excluded

There is evidence that interventions that include isolation can achieve major reductions in MRSA, even when endemic, but there are no well designed studies that allowed the role of isolation measures alone to be assessed

Studies considered to provide stronger evidence or evidence of intermediate strength provide testable hypotheses for future well planned studies

Guidelines have been produced to facilitate such research (www.hta.nhsweb.nhs.uk)

sion rate per source. ${ }^{30}{ }^{38}$ None the less, we found reports of control failure despite the employment of intensive isolation measures including isolation wards. ${ }^{31}{ }^{32}$ These studies indicate a need to investigate precisely how such isolation measures should be used. We address this question in detail elsewhere, using mathematical models to explore the effectiveness and cost effectiveness of isolation wards under different assumptions. ${ }^{16}$

\section{Strengths of the study}

In contrast with narrative reviews, ${ }^{3} 10{ }^{11}{ }^{64-67}$ where study selection may be biased, our systematic comprehensive search strategy, data extraction and documentation of component threats to validity provided a rigorous evaluation of the shortcomings of existing research. In particular, no studies tell us anything about the relative effectiveness or cost effectiveness of individual measures in different clinical situations. These would be fertile areas for further research.

Nevertheless, a lack of evidence of an effect associated with specific measures should not be mistaken for evidence of lack of effect. Having considered the evidence we believe isolation measures recommended in national guidelines should therefore continue to be applied until further research establishes otherwise.

The six studies 25262831323536 we considered to present the strongest evidence for assessing the effect of isolation, although they often failed to consider potentially important confounders, provide testable hypotheses that could be assessed in future studies.

\section{Priority for research}

MRSA is associated with substantial morbidity and mortality. ${ }^{8} 8$ The emergence of glycopeptide resistant Staphylococcus aureus 
strains, ${ }^{69}$ which further reduce therapeutic options, ${ }^{70}$ makes the implementation of well designed interventional studies to inform the choice of control measures a research priority.

Contributors: SPS coordinated writing grant proposal and conduct of review. BSC was employed as a full time postdoctorate research fellow. RI developed the search strategy together with CCK and SPS. BSC, SPS, and CCK jointly appraised abstracts. BSC and SPS independently appraised articles initially. BSC appraised articles fully and extracted data for all papers, with one of SPS, CCK, BDC, JR, GFM, and GD chosen in accordance with area of expertise. BSC with SPS and the other reviewers analysed the data. Writing up of the Health Technology Assessment report was done principally by SPS and BSC, with review and input from the whole review team. SE advised on systematic review methods in grant application and throughout review and writing up phase. The study was funded for two years by the Health Technology Assessment Board of the NHS R\&D HTA Programme.

Competing interests: None declared.

1 Public Health Laboratory Service. The first year of the Department of Health's mandatory MRSA bacteraemia surveillance scheme in acute NHS trusts in England: April 2001-March 2002. Commun Dis Rep CDR Wkly [serial online] 2002;12 www.hpa.org.uk/cdr/PDFfiles/2002/cdr2502.pdf (accessed 22 Jul 2004).

2 Hiramatsu K, Hanaki H, Ino T. Methicillin resistant Staphylococcus aureus clinica strain with reduced vancomycin susceptibility. J Antimicrob Chemother 1997;40:135-6.

3 Turnidge JD, Bell JM Methicillin-resistant Staphylococcus aureus evolution in Australia over 35 years. Microb Drug Resist 2000;6:223-9.

4 Centers for Disease Control and Prevention. National nosocomial infection surveillance systems report, data summary from January 1992-June 2001, issued August 2001. Am J Infect Control 2002;30:458-75.

5 Garner JS. Hospital infection control practices advisory commitee. Guideline for isolation precautions in hospitals. Infect Control Hosp Epidemiol 1996;17:53-80.

6 Wierkgroup Infectie Preventie. Management policy for methicillin-resistant Staphylococcus aureus. Guideline No. 35A. Leiden: WIP, 1994

7 Ministry of Health. Guidelines for the control of methicillin-resistant Staphylococcus aureus in New Zealand. Wellington: MoH, 2002. www.moh.govt.nz/moh.nsf/
49ba80c00757b8804c256673001d47d0/e5231b74a5dc8b22cc256c220017b248/ $\$$ FILE/mrsa.pdf (accessed 12 Jul 2004).

8 British Society for Antimicrobial Chemotherapy, Hospital Infection Society and the Infection Control Nurses Association. Revised guidelines for the control of methicillinresistant Staphylococcus aureus infection in hospitals.J Hosp Infect 1998;39:253-90.

9 Rahman M, Sanderson PJ, Bentley AH, Barrett SP, Karim QN, Teare EL, et al. Control of MRSA.J Hosp Infect 2000;44:151-3.

10 Boyce JM. Nosocomial staphylococcal infections. Ann Intern Med 1981;95:241-2.

11 Stone SP. Managing methicillin-resistant Staphylococcus aureus in hospital: the balance of risk. Age Ageing 1997;26:165-8.

12 Cook TD, Campbell DT. Quasi-experimentation: design and analysis issues for field settings. Chicago: Rand McNally College Publications, 1979.

13 Grimes DA, Schulz KF. Cohort studies: marching towards outcomes. Lancet 2002; 359:341-5.

14 Cochrane Effective Practice and Organisation of Care (EPOC) Review Group Cochrane Library Database. Oxford: 2001. Issue 1. Update software

15 Morton V, Torgerson DJ. Effect of regression to the mean on decision making in health care. BMJ 2003 May 17;326:1083-4.

16 Cooper BS, Stone SP, Kibbler CC, Cookson BD, Roberts JA, Medley GF, Duckworth GJ, Lai R, Ebrahim S. Systematic review of isolation policies in the hospital management of methicillin-resistant Staphylococcus aureus: a review of the literature with epidemiological and economic modelling. Health Technol Assess 2003;7:1-194.

17 Alvarez S, Shell C, Gage K, Guarderas J, Kasprzyk D, Besing J, et al. An outbreak of methicillin-resistant Staphylococcus aureus eradicated from a large teaching hospital. Am Jinfect Control 1985;13:115-21.

18 Arnow P, Allyn PA, Nichols EM, Hill DL, Pezzlo M, Bartlett RH. Control of methicillinresistant Staphylococcus aureus in a burn unit: role of nurse staffing. I Trauma 1982;22:954-9.

19 Back NA, Linnemann CC, Jr., Staneck JL, Kotagal UR. Control of methicillin-resistan Staphylococcus aureus in a neonatal intensive-care unit: use of intensive microbiologic surveillance and mupirocin. Infect Control Hospital Epidemiol 1996;17:227-31.

20 Barakate MS, Harris JP, West RH, Vickery AM, Sharp CA, Macleod C, et al. A prospective survey of current methicillin-resistant Staphylococcus aureus control measures. Austr N Z J Surg 1999;69:712-6.

21 Barakate MS, Yang YX, Foo SH, Vickery AM, Sharp CA, Fowler LD, et al. An epidemiological survey of methicillin-resistant Staphylococcus aureus in a tertiary referral hoslogical survey of methicillin-resis.
pital. J Hosp Infect 2000;44:19-26.

22 Blumberg LH, Klugman KP. Control of methicillin-resistant Staphylococcus aureus bacteraemia in high-risk areas. Eur J Clin Microbiol Infect Dis 1994;13:82-5.

23 Brady LM, Thomson M, Palmer MA, Harkness JL. Successful control of endemic MRSA in a cardiothoracic surgical unit. Med J Austr 1990;152:240-5.

24 Campbell JR, Zaccaria E, Mason EO Jr, Baker CJ. Epidemiological analysis defining concurrent outbreaks of Serratia marcescens and methicillin-resistant Staphylococcus aureus in a neonatal intensive-care unit. Infect Control Hosp Epidemiol 1998;19:924-928.

25 Coello R, Jimenez J, Garcia M, Arroyo P, Minguez D, Fernandez C, et al. Prospective study of infection, colonization and carriage of methicillin-resistant Staphylococcus aureus in of infection, colonization and carriage of methicilin-resistant Staphylococcus

26 Cosseron-Zerbib M, Roque Afonso AM, Naas T, Durand P, Meyer L, Costa et al. A control programme for MRSA (methicillin-resistant Staphylococcus aureus) containment in a paediatric intensive care unit: evaluation and impact on infections caused by other micro-organisms. J Hosp Infect 1998;40:225-35.
27 Cox RA, Conquest C, Mallaghan C, Marples RR. A major outbreak of methicillin-resistant Staphylococcus aureus caused by a new phage-type (EMRSA-16). J Hosp Infect 1995;29:87-106.

28 Duckworth GJ, Lothian JL, Williams JD. Methicillin-resistant Staphylococcus aureus: report of an outbreak in a London teaching hospital.J Hosp Infect 1988;11:1-15.

29 El Hagrasy M. An outbreak of methicillin-resistant Staphylococcus aureus (MRSA) in a hospital in the UAE: Problems and solutions. Emirates Med J 1997;15:17-21.

30 Esveld MI, de Boer AS, Notenboom AJ, van Pelt W, van Leeuwen WJ. [Secondary infection with methicillin resistant Staphylococcus aureus in Dutch hospitals (July 1994-June 1996]. Nederlands Tijdschrift voor Geneeskunde 1999;143:205-8.

31 Faoagali JL, Thong ML, Grant D. Ten years' experience with methicillin-resistant Staphylococcus aureus in a large Australian hospital. J Hosp Infect 1992;20:113-9.

32 Farrington M, Redpath C, Trundle C, Coomber S, Brown NM. Winning the battle bu losing the war: methicillin-resistant Staphylococcus aureus (MRSA) at a teaching hospital. OJM 1998:91:539-48.

33 Girou E, Pujade G, Legrand P, Cizeau F, Brun-Buisson C. Selective screening of carriers for control of methicillin-resistant Staphylococcus aureus (MRSA) in high-risk hospital areas with a high level of endemic MRSA. Clin Infect Dis 1998;27:543-50.

34 Girou E, Azar J, Wolkenstein P, Cizeau F, Brun-Buisson C, Roujeau JC. Comparison of systematic versus selective screening for methicillin-resistant Staphylococcus aureus carriage in a high-risk dermatology ward. Infect Control Hosp Epidemiol 2000;21:583-7.

35 Harbarth S, Martin Y, Rohner P, Henry N, Auckenthaler R, Pittet D. Effect of delayed infection control measures on a hospital outbreak of methicillin-resistant Staphylococcus aureus. J Hosp Infect 2000;46:43-9.

36 Pittet D, Hugonnet S, Harbarth S, Mourouga P, Sauvan V, Touveneau S, et al. Effectiveness of a hospital-wide programme to improve compliance with hand hygiene. Infection of a hospital-wide programme to improve co
Control Programme. Lancet 2000:356:1307-12.

37 Hartstein AI, LeMonte AM, Iwamoto PK. DNA typing and control of methicillinresistant Staphylococcus aureus at two affiliated hospitals. Infect Control Hosp Epidemiol 1997; 18:42-8.

38 Jernigan JA, Titus MG, Groschel DH, Getchell-White S, Farr BM. Effectiveness of contact isolation during a hospital outbreak of methicillin-resistant Staphylococcus aureus. Am J Epidemiol 1996;143:496-504.

39 Jones MR, Martin DR. Outbreak of methicillin-resistant Staphylococcus aureus infection in a New Zealand hospital. N Z Med J 1987;100:369-73.

40 Kac G, Buu-Hoi A, Herisson E, Biancardini P, Debure C. Methicillin-resistant Staphylococcus aureus. Nosocomial acquisition and carrier state in a wound care center. Arch Dermatol 2000;136:735-9.

41 Landman D, Chockalingam M, Quale JM. Reduction in the incidence of methicillin-resistant Staphylococcus aureus and ceftazidime-resistant Klebsiella pneumoniae following changes in a hospital antibiotic formulary. Clin Infect Dis 1999;28:1062-6.

42 Law MR, Gill ON, Turner A. Methicillin-resistant Staphylococcus aureus: associated morbidity and effectiveness of control measures. Epidemiol Infect 1988;101:301-9.

43 Linnemann CC, Jr., Mason M, Moore P, Korfhagen TR, Staneck JL. Methicillin-resistan Staphylococcus aureus: experience in a general hospital over four years. Am J Epidemiol 1982;115:941-50.

44 Lugeon C, Blanc DS, Wenger A, Francioli P. Molecular epidemiology of methicillin-resistant Staphylococcus aureus at a low-incidence hospital over a 4-year period. Infect Control Hospital Epidemiol 1995;16:260-7.

45 Mavall B, Martin R, Keenan AM, Irving L, Leeson P, Lamb K. Blanket use of intranasal mupirocin for outbreak control and long-term prophylaxis of endemic methicillinresistant Staphylococcus aureus in an open ward. J Hosp Infect 1996;32:257-26.

46 Murray-Leisure KA, Geib S, Graceley D, Rubin-Slutsky AB, Saxena N, Muller HA, et al. Control of epidemic methicillin-resistant Staphylococcus aureus. Infect Control Hosp Epidemiol 1990;11:343-50.

47 Onesko KM, Wienke EC. The analysis of the impact of a mild, low-iodine, lotion soap on the reduction of nosocomial methicillin-resistant Staphylococcus aureus: a new opportunity for surveillance by objectives. Infect Control 1987;8:284-8.

48 Oto MA, Pinto CME, Martinez CV, Fabio BC, Soza MA, Jerez RA, et al. Control of methicillin resistant Staphylococcus aureus at a neonatal ward. Rev Chil Pediatr 1992:63:134-8.

49 Papia G, Louie M, Tralla A, Johnson C, Collins V, Simor AE. Screening high-risk patients for methicillin-resistant Staphylococcus aureus on admission to the hospital: is it cost effective? Infect Control Hosp Epidemiol 1999;20:473-7.

50 Pearman JW, Christiansen KJ, Annear DI, Goodwin CS, Metcalf C, Donovan FP, et al Control of methicillin-resistant Staphylococcus aureus (MRSA) in an Australian metropolitan teaching hospital complex. Med J Austr 1985;142:103-8.

51 Pfaller MA, Wakefield DS, Hollis R, Frederickson M, Evans E, Massanari RM. The clinical microbiology laboratory as an aid in infection control. The application of molecular techniques in epidemiologic studies of methicillin-resistant Staphylococcus aureus. Diagn Microbiol Infect Dis 1991;14:209-17.

52 Ribner BS, Landry MN, Gholson GL. Strict versus modified isolation for prevention of nosocomial transmission of methicillin-resistant Staphylococcus aureus. Infect Control $1986 ; 7: 317-20$.

53 Schlunzen L, Lund B, Schouenborg P, Skov RL. [Outbreak of methicillin resistant Staphylococcus aureus in a central hospital]. Ugeskrift for Laeger 1997;159:431-5.

54 Selkon JB, Stokes ER, Ingham HR. The role of an isolation unit in the control of hospital infection with methicillin-resistant staphylococci. J Hosp Infect 1980;1:41-6.

55 Shanson DC, Kensit JC, Duke R. Outbreak of hospital infection with a strain of Staphylococcus aureus resistant to gentamicin and methicillin. Lancet 1976;2:1347-8.

56 Shanson DC, Johnstone D, Midgley J. Control of a hospital outbreak of methicillin-resistant Staphylococcus aureus infections: value of an isolation unit.J Hosp Infect 1985;6:285-292

57 Souweine B, Traore O, Aublet-Cuvelier B, Bret L, Sirot J, Laveran H, et al. Role of infection control measures in limiting morbidity associated with multi-resistant organisms in critically ill patients. J Hosp Infect 2000:45:107-16.

58 Stone SP, Beric V, Quick A, Balestrini AA, Kibbler CC. The effect of an enhanced infection-control policy on the incidence of Clostridium difficile infection and methicillin-resistant Staphylococcus aureus colonization in acute elderly medical patients. Age Ageing $1998 ; 27: 561-8$. 
59 Talon D, Rouget C, Cailleaux V, Bailly P, Thouverez M, Barale F, et al. Nasal carriage of Staphylococcus aureus and cross-contamination in a surgical intensive care unit: Efficacy of mupirocin ointment. J Hosp Infect 1995;30:39-49.

60 Tambic A, Power EG, Tambic T, Snur I, French GL. Epidemiological analysis of methicillin-resistant Staphylococcus aureus in a Zagreb Trauma Hospital using a randomly amplified polymorphic DNA-typing method. Eur J Clin Microbiol Infect Dis 1999:18:335-40.

61 Ward TT, Winn RE, Hartstein AI, Sewell DL. Observations relating to an inter-hospital outbreak of methicillin-resistant Staphylococcus aureus: role of antimicrobial therapy in infection control. Infect Control 1981;2:453-9.

62 Yano M, Doki Y, Inoue M, Tsujinaka T, Shiozaki H, Monden M. Preoperative intranasal mupirocin ointment significantly reduces postoperative infection with Staphylococcus aureus in patients undergoing upper gastrointestinal surgery. Surg Today 2000;30:16-21.

63 Yoshida J, Kuroki S, Akazawa K, Chijiiwa K, Takemori K, Torisu M, et al. The order of ward rounds influences nosocomial infection. A 2-year study in gastroenterologic surgery patients.J Gastroenterol 1995;30:718-24.

64 Mulligan ME, Murray-Leisure KA, Ribner BS, Standiford HC, John JF, Korvick JA, et al. Methicillin-resistant Staphylococcus aureus: a consensus review of the microbiology, pathogenesis, and epidemiology with implications for prevention and management Am J Med 1993;94:313-28.

65 Spicer WJ. Three strategies in the control of staphylococci including methicillinresistant Staphylococcus aureus.J Hosp Infect 1984;5(suppl A):45-9.

66 Bell SM. Recommendations for control of the spread of methicillin resistant Staphylococcus aureus infection. Med J Austr 1982;2:472-4.

67 Farr BM, Salgado CD, Karchmer TB, Sheretz RJ. Can antibiotic resistant nosocomai infections be controlled? Lancet Infect Dis 2001;1:38-45.

68 Crowcroft NS, Catchpole M. Mortality from methicillin resistant Staphylococcus aureus in England and Wales: analysis of death certificates. BMJ 2002;325:1390-1.

69 Centers for Disease Control and Prevention. Staphylococcus areus resistant to vancomycin-United States, 2002. Morb Mortal Wkly Rep MMWR 2002:51:565-7.

70 Perry CN, Jarvis B Linezolid: a review of its use in the management of serious gram positive infections. Drugs 2001;61:525-51

(Accepted 14 June 2004)

\section{Commentary: Golden rules}

Geoff Watts

Few events in biology offer a more powerful demonstration of the wonders of natural selection than the spread of antibiotic resistance. Hospital staff struggling to contain the golden staph may, of course, take a more jaundiced view of its triumph.

Fortunately the microbe is not invincible. This week's review by Cooper and colleagues is a reminder that strict isolation measures can limit the spread of methicillin resistant Staphylococcus aureus (MRSA). ${ }^{1}$ In a similar vein we have the recent report of a successful attempt at eradicating the organism by "ring fencing" elective orthopaedic beds. ${ }^{2}$ The consequent drop in the incidence of postoperative infection allowed surgeons to do more joint replacements. Better research is urgently needed.

The literature on infection control began with Ignaz Semmelweis, a Hungarian physician, in the mid 19th century, and is now extensive. A review by Muto et al on behalf of the Society for Healthcare Epidemiology of America provides a useful insight into our current understanding of the spread of MRSA, and so what needs to be done to combat it. ${ }^{3}$ The key to interrupting transmission is, of course, a firm understanding of what makes it possible. Do dirty rooms, dirty equipment, or dirty habits make the greatest contribution?

As many studies of MRSA have testified, hands (gloved or otherwise) are still the leading culprit. And transmission does not have to be direct. One investigation showed that almost half of the gloves worn by a group of nurses became contaminated with MRSA when they touched not the patients themselves, but various surfaces in the rooms where those patients were being nursed. Another study found the microbe on the keyboards of computers used only by clinicians.

There's evidence too of MRSA from gowns, white coats, all manner of portable equipment from stethoscopes to pagers, domestic items such as mops and furniture, and many types of
University Department Medical Microbiology, Royal Free Campus, Royal Free and University College Medical School, University London, London NW3 2PF] B S Cooper postdoctoral research fellow C C Kibbler postdoctoral research fellow

Academic Department Geriatric Medicine, Royal Free Campus, Royal Free and University College Medical School

S P Stone senior lecturer

Laboratory of Healthcare Associated Infection, Central Public Health, Laboratory, Health Protection Agency, London NW9 5HT

B D Cookson director

Collaborative Centre for Economics of Infectious Disease, Department Public Health and Policy, London School of Hygiene and Tropical Medicine, University London WC1E 7HT

$\mathrm{J}$ A Roberts professor in economics of infectious disease

Department of Biological Sciences, University of Warwick, Coventry CV4 7AL UK G F Medley reader, ecology and epidemiology

Division of Healthcare Associated Infection and Antimicrobial Resistance, Health Protection Agency, Communicable Disease Surveillance Centre, London NW9 5EQ

G Duckworth director

University Library, Royal Free Campus, Royal Free and University College Medical School

R Lai assistant librarian

Department of Social Medicine, Bristol University Medical School, University of Bristol BS8 2PR

S Ebrahim professor in epidemiology of ageing

Correspondence to: S P Stone s.stone@rfc.ucl.ac.uk

bmj.com 2004;329:533

environmental surface. In one hospital more than a quarter of 350 surfaces tested in the rooms of 38 patients colonised by MRSA were positive for the organism.

All this one might have suspected; more worrisome is the period for which the microbe can continue to pose a threat. One study of the outer surfaces of packages of sterile goods revealed the presence of MRSA that had survived for more than 38 weeks.

Given the part that antibiotics have played in fostering the emergence of resistant strains, it comes as something of a disappointment to learn that strict policies to limit their use are not enough to reverse the trend. Once MRSA has gained a foothold, there is, it seems, little correlation between its prevalence and the parsimonious use of antibiotics. Finland, the United Kingdom, and Italy all consume roughly the same amounts of these drugs, but they have big differences in the proportion of methicillin resistant isolates.

In short, while antibiotics do give the golden genie a selective advantage over its susceptible brethren once it has escaped its bottle, squeezing it back from whence it came depends principally on sustained efforts at preventing transmission. When it comes to regular hand washing, at least one survey has suggested that doctors are more blameworthy than nurses.

So, once more unto the sink, dear friends, once more...

1 Cooper BS, Stone SP, Kibbler CC, Cookson BD, Roberts JA, Medley GF, et al. Isolation measures in the hospital management of methicillin resistant Staphylococcus aureu (MRSA): systematic review of the literature. BMJ 2004;329:533-8.

2 Biant LC, Teare EL, Williams WW, Tuite JD. Eradication of methicillin-resistant Staphylococcus aureus by "ring fencing" of elective orthopaedic beds. BMJ 2004;329:149-51.

Muto CA, Jernigan JA, Ostrowsky BE, Richet HM, Jarvis WR, Boyce JM, et al. SHEA guidelines for preventing nosocomial transmission of multi-drug resistant strains of Staphylococcus aureus and Enterococcus. Infect Control Hosp Epidemiol 2003;24:362-86.

28 New End Square, London NW3 1LS

Geoff Watts science editor, BMJ geoff@scileg.freeserve.co.uk 